\title{
Penyelesaian Soal Limit Fungsi Trigonometri dengan Solusi Cepat pada siswa SMA
}

\author{
Iin Ariyanti ${ }^{\mathrm{a}, 1, *}$, Nafisa Nur Zaqiyah ${ }^{\mathrm{b}, 2}$ \\ a,b Universitas Muhammadiyah Banjarmasin, Jl. Gubernur H. Syarkawi,Barito Kuala, Kalimantan-Selatan, Indonesia \\ 1 iin.ariyanti1105@gmail.com* \\ * corresponding author
}

ARTICLE INFO

Keywords

Trigonometry Function

Limits;

Quick Solution;

High school student

\begin{abstract}
$A B S T R A C T$
The purpose of this service is to help students deal with the shortage of time when working on multiple choice math problems, especially in the trigonometric function limit material. This activity was carried out on April 24, 2019 at SMAN 1 Tamban, Barito kuala, South Kalimantan, attended by 25 students as participants. The implementation of this activity consists of opening and introduction, explanation and application of problem solving, then practice questions and gift giving, as well as closing and group photos. The material for the quick solution of trigonometric function limit problem solving consists of trigonometric limits using the spruck rules, trigonometric limits using the delete rules of "evil" cosines, and trigonometric limits using the "good" cosine change rules. In the midst of community service activities, the service team appealed to students to prioritize understanding of mathematical concepts in solving mathematical problems. Quick solutions are recommended to be used only on multiple choice tests and force students to solve problems in a short time. Overall, this activity went well and smoothly and without significant obstacles.
\end{abstract}

\section{PENDAHULUAN}

Permasalahan yang sering terjadi pada siswa SMA saat menghadapi tes ujian di sekolah, tes seleksi masuk perguruan tinggi, dan tes seleksi lainnya yang bersifat pilihan ganda yaitu kurangnya waktu dalam mengerjakan soal. Selain itu, soal-soal matematika biasanya membutuhkan waktu yang tidak sedikit dalam melakukan perhitungan, ditambah lagi jika siswa kurang teliti sehingga jawaban pada pilihan ganda tidak ditemukan dan siswa harus mengulang kembali untuk memeriksa perhitungannya sehingga menghabiskan waktu pengerjaan. Berdasarkan penelitian yang dilakukan oleh Wasida \& Hartono (2018) kesulitan yang dialami siswa dalam menyelesaikan soal model Ujian Nasional matematika disebabkan oleh beberapa faktor diantaranya adalah ketidakmampuan dalam operasi aljabar, lupa, kurang teliti, terburu-buru, cepat menyerah, waktu yang kurang, kurangnya kesiapan dan keaktifan siswa. Oleh karena itu, untuk menyiasati hal tersebut siswa perlu mempelajari cara yang membutuhkan waktu relatif singkat serta efektif dalam menyelesaikan soal tersebut.

Salah satu materi matematika adalah limit fungsi trigonometri. Dalam mengerjakan limit fungsi trigonometri, siswa merasa kesulitan dalam menyelesaikan soal tersebut. Hal ini didasarkan pada hasil identifikasi kesalahan siswa dalam menyelesaikan limit trigonometri pada 23 siswa yang disampaikan oleh Alfiannor (2016) dimana dalam menerapkan rumus dasar limit fungsi trigonometri tingkat kesalahan siswa sebesar $94,56 \%$, pada menguraikan bentuk soal tingkat kesalahan siswa sebesar 86,95 \%, kesulitan menerapkan teorema limit utama tingkat kesalahan siswa sebesar $65,21 \%$ dan kesulitan dalam melakukan operasi hitung/komputasi tingkat kesalahan siswa sebesar 52,70\%. Dapat dilihat bahwa kesalahan terbesar yang paling sering diakukan oleh siswa adalah menerapkan rumus dasar limit fungsi trigonometri. Hal ini cukup menggambarkan bahwa siswa kesulitan dalam menyelesaikan soal limit fungsi trigonometri.

Soal limit fungsi trigonometri ini dapat disiasati dengan menggunakan cara cepat dan relatif mudah. Kegiatan pengabdian ini bertujuan untuk mengajarkan siswa solusi cepat dalam menyelesaikan soal limit fungsi trigonometri. Meskipun tim pengabdian mengajarkan metode cepat untuk menyelesaikan limit fungsi trigonometri, bukan berarti bahwa tim pengabdian mengajarkan 
siswa untuk menomorduakan proses pemahaman konsep matematika. Tim pengabdian tetap menghimbau kepada siswa untuk tetap mengutamakan proses pemahaman konsep dalam pembelajaran matematika serta hanya menggunakan cara ini dalam tes yang bersifat pilihan ganda. Karena jika siswa mempelajari tanpa pemahaman maka siswa belajar seperti kepingan yang terpotong-potong (Dahlan, 2011) serta pemahaman yang bersifat relasional lebih mudah diadaptasikan dengan persoalan baru (Skemp, 1976).

Akan tetapi meskipun begitu, penggunaan metode cepat (shortcut) dalam matematika pada dasarnya tidaklah buruk, kunci penggunaannya yaitu terletak pada urutan pembelajaran konsep matematika. Ketika siswa benar-benar menguasai konsep matematika, maka siswa dapat menunjukkan semua langkah-langkah rinci dalam proses penyelesaian masalah, menjelaskan mengapa langkah-langkah itu dipilih, dan mampu menghubungkan proses dengan konsep terkait. Begitu siswa mencapai tingkat pemahaman ini, maka seorang guru kemudian dapat mengajarkan siswa cara yang lebih efisien untuk mengekspresikan atau melakukan proses yang sama (Molina, 2014)..

\section{PELAKSAAAN DAN METODE}

Kegiatan ini dilaksanakan pada hari rabu, 24 April 2019 di SMAN 1 Tamban, Barito Kuala, Kalimantan Selatan. Tim pengabdian ini terdiri dari Iin Ariyanti, M.Pd dan dibantu oleh Nafisa Nurdzaqiyah yang merupakan mahasiswa pendidikan matematika. Adapun jadwal kegiatan pengabdian dapat dilihat pada tabel berikut.

Tabel 1. Jadwal kegiatan pengabdian

\begin{tabular}{clc}
\hline No. & \multicolumn{1}{c}{ Kegiatan } & Waktu \\
\hline 1 & Pembukaan dan perkenalan & $09.30-10.00$ \\
2 & Penjelasan dan Penerapan penyelesaian Soal & $10.00-11.00$ \\
3 & Latihan Soal dan Pemberian Hadiah & $11.00-12.00$ \\
4 & Penutupan dan Foto bersama & $12.00-12.15$
\end{tabular}

Adapun materi solusi cepat penyelesaian soal limit fungsi trigonometri didasarkan pada referensi oleh Anang (2013) yang dijelaskan sebagai berikut.

1. Limit Trigonometri menggunakan aturan sinta coret.

Limit trigonometri yang memuat bentuk sinus atau tangen dimana $\mathrm{x}$ mendekati nilai 0 dan menghasilkan bentuk tak tentu $\frac{0}{0}$ maka dapat menggunakan solusi cepat yaitu dengan mencoret sinus dan tangen kemudian menyederhanakan bentuk yang tersisa. Perhatikan gambar berikut ini.

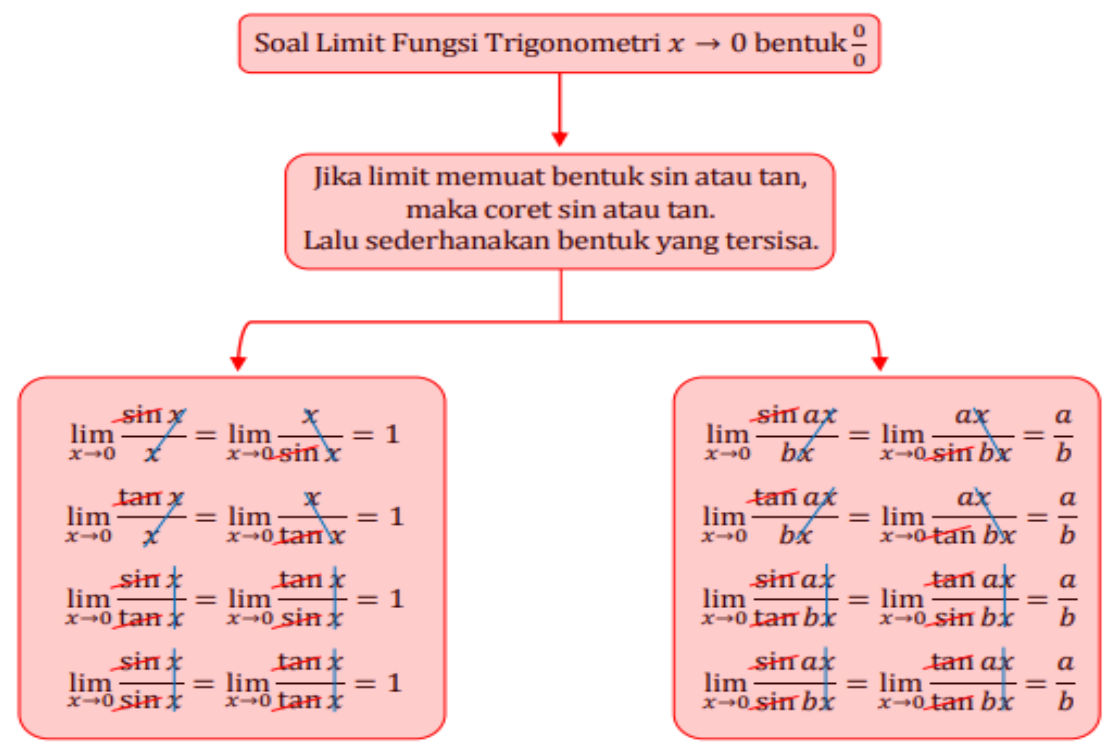

Gambar 1. Limit trigonometri menggunakan aturan sinta coret 
2. Limit Trigonometri menggunakan aturan hapus cosinus jahat Limit trigonometri yang memuat bentuk cosinus jahat dimana $\mathrm{x}$ mendekati nilai 0 dan menghasilkan bentuk tak tentu $\frac{0}{0}$ maka dapat menggunakan solusi cepat yaitu menghapus fungsi cosinus yang bernilai 1 . Perhatikan gambar berikut ini.

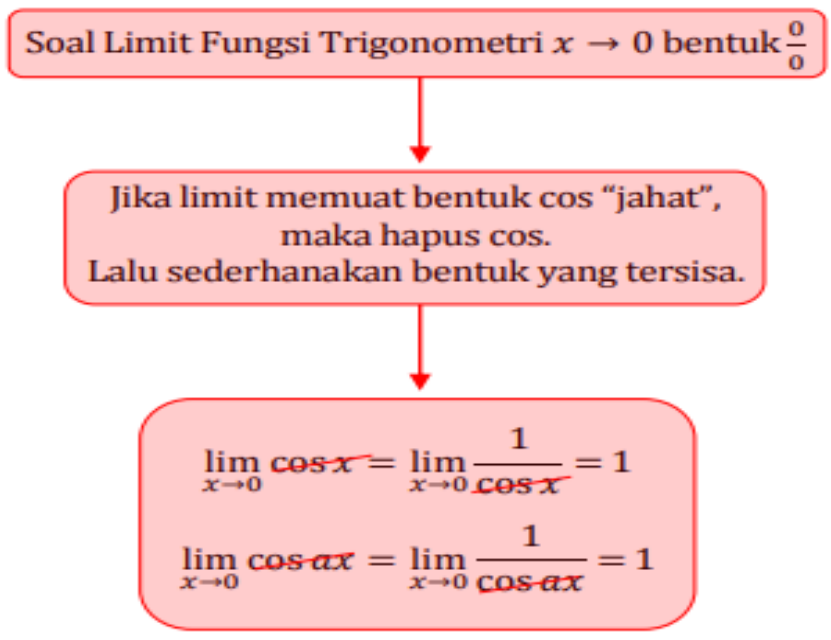

Gambar 2. Limit trigonometri menggunakan aturan hapus cosinus "jahat"

3. Limit Trigonometri menggunakan aturan ubah cosinus "baik"

Limit trigonometri yang memuat bentuk cosinus "baik" (cosinus baik adalah cosinus yang menyebabkan nilai limit menjadi 0) dimana $\mathrm{x}$ mendekati nilai 0 dan menghasilkan bentuk tak tentu $\frac{0}{0}$ maka dapat menggunakan solusi cepat yaitu dengan mengubah fungsi cosinus yang menyebabkan nilai limit menjadi 0 dengan menggunakan sifat identitas trigonometri. Perhatikan gambar berikut.

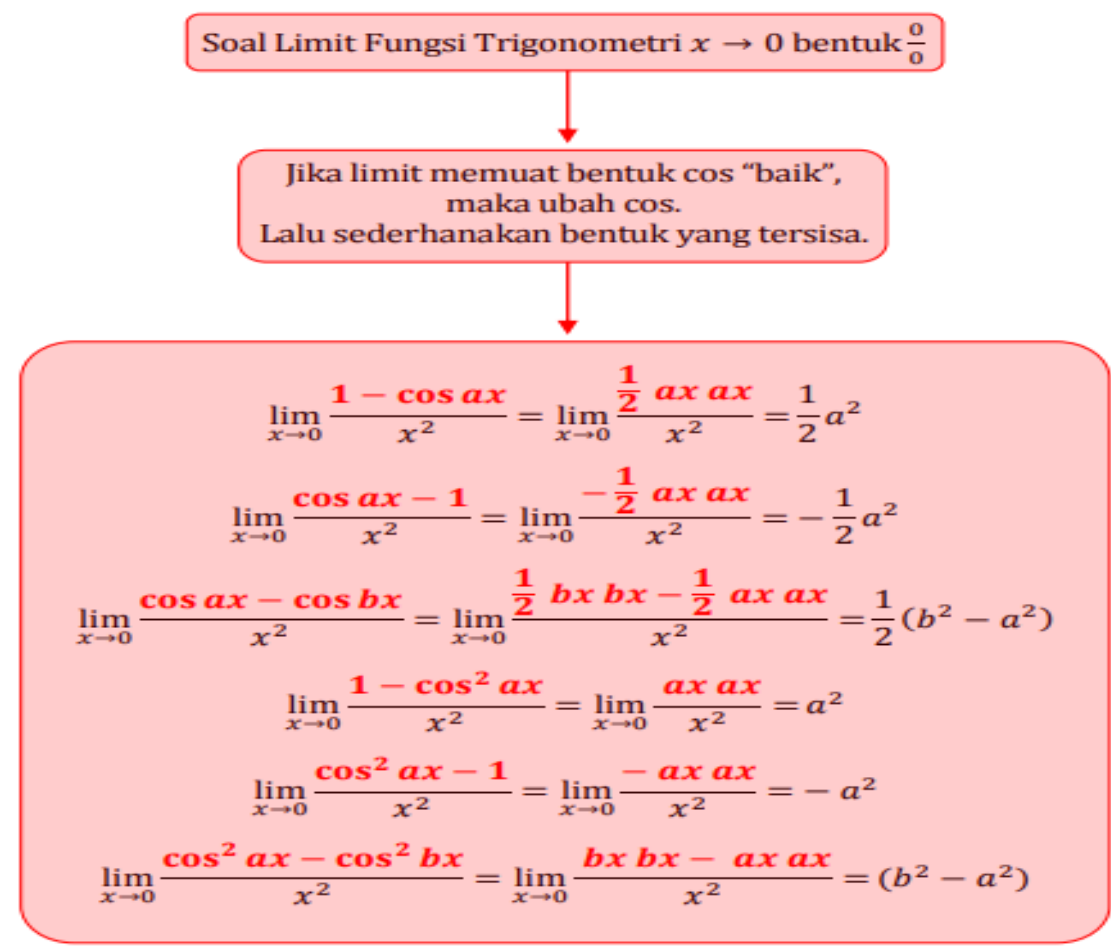

Gambar 3. Limit trigonometri menggunakan aturan ubah cosinus "baik"

Penyelelesaian limit fungsi trigonometri dimana $x \rightarrow 0$ secara konseptual didasarkan pada aturan substitusi pada fungsi limit trigonometri dan teorema limit trigonometri khusus (Varberg, Purcell, \& Rigdon, 2010) yaitu 


$$
\lim _{x \rightarrow 0} \frac{\sin x}{x}=1 \quad \lim _{x \rightarrow 0} \frac{1-\cos x}{x}=0
$$

Berikut ini adalah contoh penerapan penyelelesaian limit fungsi trigonometri dimana $x \rightarrow 0$ dengan solusi biasa dan solusi cepat.

Contoh 1:

$\lim _{x \rightarrow 0} \frac{\sin 3 x}{x}=\lim _{x \rightarrow 0} 3 \frac{\sin 3 x}{3 x}=3 \lim _{x \rightarrow 0} \frac{\sin 3 x}{3 x}=3$

Solusi cepat sinta coret:

$\lim _{x \rightarrow 0} \frac{\sin 3 x^{\prime}}{x}=3$

Contoh 2:

$\lim _{x \rightarrow 0} \frac{\sin 4 x}{\tan x}=\lim _{x \rightarrow 0} \frac{\frac{4 \sin 4 x}{4 x}}{\frac{\sin x}{x \cos x}}=\lim _{x \rightarrow 0} \frac{4 \lim _{x \rightarrow 0} \frac{\sin 4 x}{4 x}}{\left(\lim _{x \rightarrow 0} \frac{\sin x}{x}\right)\left(\lim _{x \rightarrow 0} \frac{1}{\cos x}\right)}=\frac{4}{1.1}=4$

Solusi cepat sinta coret:

$\lim _{x \rightarrow 0} \frac{\sin 4 x}{\tan x}=4$

Contoh 3:

$\lim _{x \rightarrow 0} \frac{\cos x}{x+1}=\frac{\lim _{x \rightarrow 0} \cos x}{\lim _{x \rightarrow 0} x+1}=\frac{\cos 0}{0+1}=\frac{1}{1}=1$

Solusi cepat menggunakan aturan hapus cosinus jahat $\lim _{x \rightarrow 0} \frac{\cos x}{x+1} \stackrel{\frac{1}{=0+1}}{=1}$

Contoh 4:

$\lim _{x \rightarrow 0} \frac{1-\cos 6 x}{\sin x \tan 3 x}=\lim _{x \rightarrow 0} \frac{1-\left(1-2 \sin ^{2} 3 x\right)}{\sin x \tan 3 x}=\lim _{x \rightarrow 0} \frac{2 \sin 3 x \cdot \sin 3 x}{\sin x \tan 3 x}=2.3 .1=6$

Solusi cepat menggunakan aturan ubah cosinus baik dan aturan sinta coret

$\lim _{x \rightarrow 0} \frac{1-\cos 6 x}{\sin x \tan 3 x}=\frac{\frac{1}{2} \cdot 6 x \cdot 6 x}{x \cdot 3 x}=6$

Dalam menerapkan penyelesaian limit fungsi trigonometri menggunakan solusi cepat, siswa disarankan untuk memahami aturan penerapannya secara benar. Karena jika penerapannya tidak sesuai dengan aturan solusi cepat, maka khawatirnya siswa akan mendapatkan jawaban yang tidak tepat. Oleh karena itu, sebaiknya siswa mengaitkannya secara logis dengan penyelesaian limit fungsi trigonometri menggunakan aturan substitusi dan teorema limit trigonometri khusus. Namun, jika siswa menguasai penerapan aturan solusi cepat dengan benar, maka metode ini dapat menguntungkan bagi siswa pada saat menyelesaikan soal dengan pilihan ganda dalam waktu yang singkat. Siswa juga dapat membandingkan hasil jawaban penerapan aturan solusi cepat untuk mengecek kesalahan perhitungan pada saat menyelesaikan limit fungsi trigonometri dengan solusi biasa.

\section{HASIL DAN PEMBAHASAN}

Secara keseluruhan, kegiatan pengabdian ini berjalan dengan cukup baik dan tanpa kendala yang berarti. Kegiatan pengadian dilaksanakan di kelas yang dihadiri oleh 25 siswa sebagai peserta kegiatan pengabdian ini. Pelaksanaan kegiatan diawali dengan pembukaan dan perkenalan dimana tim pengabdian memperkenalkan diri serta menyampaikan tujuan pelaksanaan pengabdian. Pada awal kegiatan ini juga tim pengabdian melibatkan interaksi dengan para peserta dengan memberikan pertanyaan pertanyaan sederhana seperti perkenalan nama, apakah ada yang menyukai 
matematika, rencana setelah lulus dan sebagainya. Tujuannya adalah untuk membangun ikatan dengan peserta sebelum melaksanakan inti kegiatan serta memberikan motivasi kepada peserta untuk melanjutkan pendidikan ke jenjang yang lebih tinggi. Kemudian dilanjutkan pada kegiatan inti pelaksanaan yang diawali dengan pemberian soal limit fungsi trigonometri. Tim pengabdian memberikan materi cetak yang berisi materi solusi cepat penyelesaian limit fungsi trigonometri kepada seluruh peserta. Tim pengabdian menjelaskan bahwa terdapat solusi yang lebih cepat dalam mengerjakan soal tersebut dan dapat dilihat pada materi yang telah dibagikan. Tim pengabdian menyampaikan beberapa tipe solusi cepat dalam mengerjakan jenis limit fungsi trigonometri dan memberikan contoh soal pengerjaannya. Selanjutnya tim pengabdian memberikan latihan soal limit fungsi trigonometri kepada peserta dan meminta siswa untuk menyelesaikan soal soal tersebut dengan menggunakan solusi cepat. Beberapa siswa maju ke depan menyampaikan hasil jawabannya di papan tulis. Selanjutnya peserta-peserta yang sudah maju menyampaikan hasil jawabannya diberikan hadiah berupa alat tulis sebagai apresiasi kepada peserta. Kegiatan ditutup dengan mengucapkan hamdalah atas kelancaran kegiatan ini dan ucapan terima kasih kepada peserta yang sudah antusias dalam mengkuti kegiatan pengabdian serta permohonan maaf jika terdapat kesalahan yang tidak disengaja baik kata-kata maupun perbuatan. Di akhir kegiatan sebagai bentuk dokumentasi kegiatan, tim pengabdian bersama-sama dengan peserta melakukan foto bersama. Foto-Foto dokumentasi kegiatan dapat dilihat pada gambar-gambar berikut ini.

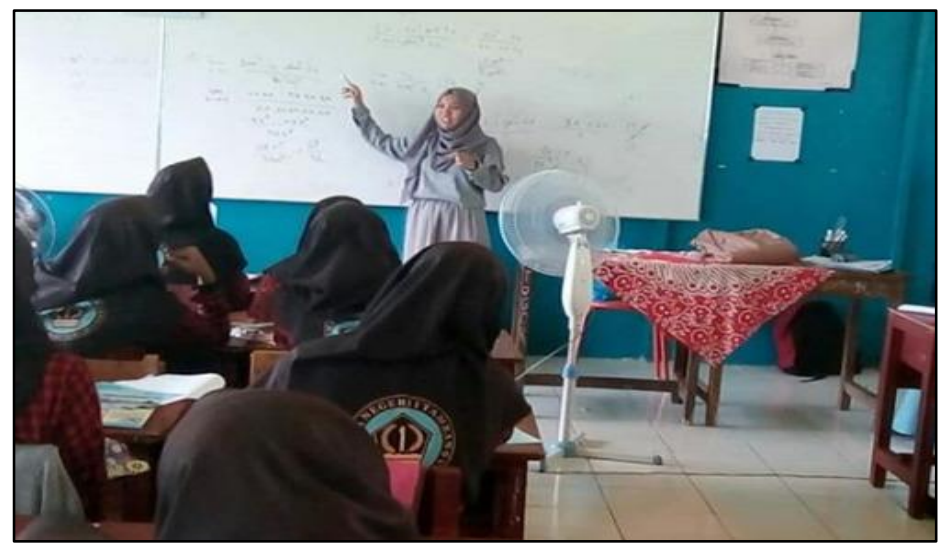

Gambar 4. Pemberian contoh soal

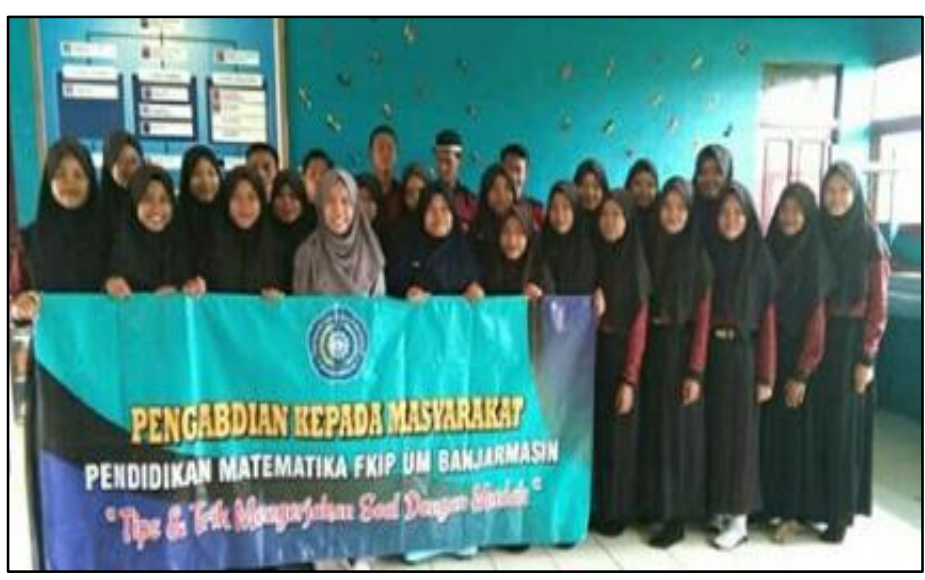

Gambar 5. Foto bersama dengan peserta

\section{PENUTUP}

Kegiatan pengabdian ini bertujuan untuk membantu siswa dalam mensiasati kekurangan waktu pada saat mengerjakan soal matematika pilihan ganda khususnya pada materi limit trigonometri. Dalam menyelesaikan soal matematika, tim pengabdian tetap menghimbau kepada siswa untuk lebih mengutamakan pemahaman konsep-konsep matematika dalam menyelesaikan masalah matematis. Solusi cepat hanya diajurkan untuk digunakan pada tes pilihan ganda dan memaksa kita untuk menyelesaikan soal dalam waktu yang singkat. 


\section{DAFTAR PUSTAKA}

Alfiannor. (2016). Identifikasi Kesulitan dalam Menyelesaikan Soal-Soal Limit Fungsi Trigonometri pada Siswa Kelas XI IPA MA PIP (Pendidikan Islam Parigi) Habirau Tengah. Jurnal PTK \& Pendidikan Vol. 2 No. 2. Juli - Desember 2016 , 1-9.

Anang. (2013). Smart Solution UN Matematika SMA 2013 (SKL 5.1 Limit Fungsi Aljabar dan Limit Fungsi Trigonometri). Dipetik April 2019, dari http://pakanang.blogspot.com/2013/01/smart-solution-un-matematika-sma-2013_23.html

Dahlan, J. A. (2011). Analisis Kurikulum Matematika. Jakarta: Universitas Terbuka.

Molina, C. “. (2014). Teaching Mathematics Conceptually. SEDL insights Vol. 1, No. 4, Winter 2014, 1-8.

Skemp, R. R. (1976). Relational understanding an instrumental understanding. First Published in Mathematics Teaching, 77, 20 -26.

Varberg, D., Purcell, E. J., \& Rigdon, S. E. (2010). Kalkulus Edisi Kesembilan Jilid 1. Jakarta: Erlangga.

Wasida, M. R., \& Hartono, H. (2018). Analisis kesulitan menyelesaikan soal model ujian nasional matematika. Jurnal Riset Pendidikan Matematika 5 (1), 82-95. 